\title{
The Applicability of Governance at King Saud University in Riyadh
}

\author{
Mohammad Y. Kentab \\ Ph.D. in Educational Administration, Advisor at the Deputyship for Planning \& Information, Ministry of Education, \\ Kingdom of Saudi Arabia
}

Copyright $(\mathrm{C} 2018$ by authors, all rights reserved. Authors agree that this article remains permanently open access under the terms of the Creative Commons Attribution License 4.0 International License

\begin{abstract}
The problem of the study revolves around the application of the requirements of governance at King Saud University. The study aims to identify the extent of governance requirements at King Saud University as seen by faculty members through transparency, accountability, organizational structure, laws, regulations, and justice. To achieve the objectives and procedures of the study, the survey descriptive methodology was used. The study population was represented by faculty members at King Saud University. A sample of 200 faculty members was selected. The researcher relied in data collection on the questionnaire, which was subjected to the standards of validity and consistency, and used various appropriate statistical methods using (SPSS). The study reached several results, the most important of which are: 1 . The level of transparency, accountability and justice at the university is average. 2. The level of organizational structure, laws and regulations in the university is high. In the light of the results, a number of recommendations were made that could contribute to the application of governance at the university.
\end{abstract}

Keywords Universities, Governance, Accountability, Higher Education

\section{Introduction}

Recent years have witnessed the emergence of the term governance in all fields, especially administrative ones, and exceeded that to express its themes and terminology in other fields such as accounting and finance. Governance has been one of the most important topics since the mid-1990s. So far, it has attracted the attention of researchers in various fields of knowledge and international and professional organizations alike, as a means of achieving comprehensive control over the work of organizations and against poor management practices. Which led many organizations to reconsider existing management tools and to develop entirely new management tools (Al-Nassar, 2014) [7].

The rules and regulations of governance aim to achieve transparency and fairness and to grant the right of accountability to the management of the organization, taking into account the reduction of the exploitation of power other than in the public interest. These rules also emphasize the importance of adhering to the provisions of the law and endeavor to ensure audit of the financial performance, existence of administrative structures to enable governing the management, with the formation of an audit committee of non-members of the executive board with many functions, competencies and powers to achieve independent control over implementation.

Governments and organizations have become increasingly interested in governance as a way to implement a set of guidelines to improve their performance as a result of administrative, economic and political pressures due to globalization that allowed expansion of activity volume, transfer of capitals across borders, weakened control on them, in addition to the various economic collapses and successive financial crises (Nassar, 2015) [21].

Governance is one of the most prominent concepts that have been raised at the academic level of management. It includes the transition from government administration in its traditional sense to a new situation that combines the forces of society, including governance, civil society organizations, and the private sector. Moreover, the government agency is no longer the only one to draw and implement the various plans and activities within the community, but it has become a partner of other community forces that have multiple interests and are at times intertwined. The idea of governance emerged in the last three decades of the last century, especially by international organizations as a methodology for achieving community development because of the decreasing ability of government agencies to achieve this efficiently and effectively (Al-Hudayef, 2008) [5].

The application of governance in universities as a successful solution to a range of problems suffered by the universities emerged during the horizontal expansion. The 
administrative layers added over the past years have stifled the ability of universities to move towards a rational and coherent strategic system, limiting the effectiveness of higher education under a group of clear expectations and identification of accountability and transparency frameworks that include both structures and instructions as well as ongoing assessment to eliminate defects that arise in both enactment and enforcement phases. The emergence of the governance input in universities is aimed at finding solutions to these problems experienced by higher education institutions (Abu Kareem, Al-Thwaini, 2014) [3].

\subsection{Problem of the Study}

The university education is the cornerstone for building the individual and giving him a scientific, cultural, social and cognitive formation that helps in the development of human resources in all the specializations required by the labor market. The university education - within the comprehensive educational policy framework - is a key base for development as it is essential in urging the talents, capabilities and human potentials in the society. It is also the tool that contributes to the formation of the individual and the society, the crystallization of its features in the present and the future together, and ensuring the proper ways for the nation to progress towards its goals in progress and promotion (Dahawi and Al-Meligi, 2011) [16].

The importance of the governance of universities has increased in recent years due to considerations including that the government represents the main reference for determining the objectives of higher education institutions and managing their resources and components according to the rules of transparency, participation, and accountability in order to improve education according to the interests of students and society. Governance processes are mainly concerned with the extent of the university's coherence as an organization, how it exercises its authority, its contact with faculty members and students, how decisions are made and power delegation, the role of university councils, leadership and the organizational structures of the university organization, as well as the various procedures and rules governing the work, the general policies that govern and allocate resources, follow-up and performance management. (Abu Kareem, Al-Thwaini, 2014) [3].

Although Saudi universities are aiming to achieve quality and excellence in university performance through the implementation of standards to ensure the quality of education and accreditation, which primarily include the standards of leadership and governance as a major determinant of the quality of education, the attempts to develop higher education institutions did not achieve the expected success due to lack of complete understanding to the concepts of governance by some university leaders, and members of the faculty at some universities, and hence comes this study to address the governance systems at King Saud University. The problem of the study can be shaped by the following question: To what extent the requirements of governance at King Saud University are applied?

\subsection{Importance of the Study}

This study derives its importance from the importance of its subject matter which is the extent to which the requirements of governance at King Saud University are applied as seen by the faculty members through the organizational structure, academic support, professional development, regulations and laws, facilities and equipment and administrative control. The scientific and practical importance of the study can be determined through the following:

\subsubsection{Scientific Importance}

This study contributes to the definition of the importance of university governance, as the importance of university governance has increased in recent years due mainly to the fact that governance is the organizing framework for determining the objectives of higher education institutions and managing their resources and components.

The importance of shedding light on the subject of governance, and clarifying the degree of the application at the university is a method of modern management to improve the performance of the university.

To enrich the subject of governance in higher education, as many of the literature dealt with governance in other universities and the business and corporate sectors.

This study encourages further studies on governance.

\subsubsection{Practical Importance}

The results of this study are expected to help the faculty members at King Saud University understand the positive aspects of governance that will affect their decision-making and thus the university's performance. This perception will be largely reflected in the means they use to prioritize the work and thus their relationships with each other and with their subordinates in order to achieve these priorities, and helps to give them a vision of the governance of the university.

\subsection{Study Objective}

The study aims at identifying the degree of application of governance requirements at King Saud University from the point of view of the faculty members through transparency, accountability, organizational structure, laws and regulations, and justice.

\subsection{Study Question}

What is the degree of application of governance requirements at King Saud University from the point of 
view of the faculty members through transparency, accountability, organizational structure, laws and regulations, and justice?

\subsection{Terminology of the Study}

\subsubsection{Governance in the Language}

The origin of governance in Arabic language is the verb "Govern." In the Arabic dictionary "Lesan Alarab", we find that the Arabs say: "Hakmat", means ruled and controlled; in other words, you have forbidden and controlled; and from this the ruler was told among the people a ruler, because he forbids the oppressor from injustice; and from the meanings of the word "Ruling on": Ruling on something and judging it both: Preventing it from corruption (Ibn Manzoor, 1983, pp. 951-952) [15].

\subsubsection{Governance in Terminology}

Governance has many definitions, including "a set of laws, regulations, and decisions aimed at achieving quality and excellence in performance by selecting appropriate and effective methods to achieve the organization's plans and objectives" (Halawa, Taha, 2014, p. 34) [14].

Governance is also defined as "the system through which the organization's work is directed and monitored at the highest level in order to achieve its objectives and to meet the standards of responsibility, integrity, and transparency" (Al-Alawi, 2014, p. 22) [4].

\subsubsection{Procedural Definition of Governance}

The procedural definition of governance is that it reflects a range of actions, including transparency, accountability, organizational structure, regulations and laws, and justice, which aim at achieving quality and excellence in performance by selecting appropriate and effective methods to achieve the University's plans and objectives.

\subsection{The Study Limits}

\subsubsection{Objective Limits}

The study is limited to investigating the issue of the applicability of governance at King Saud University, with a focus on transparency, accountability, organizational structure, laws and regulations, and justice aiming at achieving quality and excellence in performance by selecting appropriate and effective methods to achieve the University's plans and objectives.

\subsubsection{Human Limits}

The study was limited to faculty members of the theoretical colleges at King Saud University amounting (430) members. The theoretical colleges were chosen because their members are close to the subject of the study, especially the faculty members specialized in public administration, educational administration, business administration, education and literature.

\subsubsection{Spatial Limits}

The study was applied at King Saud University in Riyadh. The reason for choosing this university is that it is one of the largest and oldest universities in the Kingdom of Saudi Arabia. It is considered the best university in the Kingdom because it has a world ranking in quality and academic accreditation. It is considered an example to the other universities in Saudi Arabia.

\subsubsection{Time Limits}

The present study was completed during 2017 .

\section{Theoretical Framework and Literature}

\subsection{Theoretical Framework}

\subsubsection{The Concept of University Governance}

The governance of university education means the way in which its activities are directed, managed and monitored through formal and informal arrangements that allow colleges and universities to make decisions and take actions that achieve objectives and discuss outstanding issues of interest to individuals within and outside higher education institutions (Abdul Hakim, 2011, p 318) [1].

It is also a "set of activities, processes, and procedures at the university-wide level, linked together through a network of laws, policies and persons. It organizes and directs the interrelationship between many stakeholders who exchange interest and influence with the University administration, through a comprehensive and complex oversight system that Influences the way the university is directed, managed and controlled "(Nasser Al-Din, 2012, p. 15) [22].

University governance is also defined as "the methods and means by which the university determines its direction and organizes itself to achieve its purpose, including important meanings such as accountability, transparency, integrity, independence, collective decision-making, and law enforcement." (Mahmoud, 2011, p. 67) [19].

It is also seen as the ability of universities to achieve their goals at a high level of quality and to improve their performance through effective plans and methods through good governance (Al-Oraini, 2014, p. 17) [8].

University governance is defined as the set of variables of relationships between university administration, its members, and the external community within the following areas: organizational structure, academic support, professional development, regulations and laws, and administrative control (Abu Kareem, 2014, p. 72) [3]. This is in line with the definition of Bratianu (2015), who shows that university governance is an intellectual concept that illustrates the way the university is managed through its political, economic, educational and social content 
(Bratianu, 2015, p.2) [10].

Through the above, university governance is defined as the methods and means by which the university determines its direction and organizes itself for the purpose of its existence, including its important values such as accountability, transparency, integrity, independence, collective decision-making, and adherence to the law. The researcher believes that the form of governance adopted by the universities determines values, trends, management, strategy, decision-making systems, how to meet the needs of the beneficiaries, and how the university sees itself and its relationship with other universities, with the purpose of achieving the university's objectives.

\subsubsection{The Importance of University Governance}

Governance is of great importance in universities, because it provides the organizational structure through which university goals can be achieved, the means to achieve those goals, and performance control, and can be identified in the management of universities as follows:

- It contributes to the creation of independent organizations with governing councils and bodies responsible for determining the strategic direction of these organizations and ensuring the effectiveness of their management.

- It helps universities achieve their goals in the best possible way.

- It benefits in detecting deficiencies in performance and weak outputs.

- Ensure a balance between long-term strategic responsibilities and short-term operational responsibilities.

- Governance helps to enhance competitiveness and avoid administrative and financial corruption of universities.

- Ensures the resources of universities and their optimal investment.

- Ensures the rights and interests of employees of the administrative and academic bodies without discrimination.

- Governance is a system of supervision and self-control, which leads to the safety of the legal application of legislation, and thus better management and guarantee the rights of workers, and to achieve the satisfaction of society about universities and their performance (Al-Oraini, 2014, p. 118) [8].

- Governance helps the senior management of the university to ensure that its employees apply the rules and procedures specified for them.

- Higher education institutions that apply good governance have a more competitive advantage than those that do not apply governance.

- Good governance is an essential element in improving the productive and financial efficiency of universities.
- Governance is a system whereby the performance of university staff is monitored and evaluated well and effectively (Khudair, 2012, p. 184) [17].

The researcher explains that governance is one of the most important processes necessary for the proper functioning of university institutions, and the assurance of the integrity of the administration, as well as the fulfillment of obligations and commitments and to ensure the achievement of the university institutions for their objectives and in a sound legal manner and in order to preserve the interests of all parties, demonstrating the importance of governance.

\subsubsection{Objectives of University Governance}

The aim of governance as a new administrative input for university education is to reach the creative management of the university education system by implementing measures that aim to change for the better in the different areas of the educational system: objectives, policies, administrative leadership, organizational structure, legislation, human resources, regulatory environment, information systems management, control and partnership with the production and service sectors, and thus governance aims to make a qualitative leap in the university education system, whether in terms of planning, implementation or follow-up (Abdel Hakim, 2011, p. 318) [1]. Through this, university governance aims at the following (Al-Oraini, 2014, p. 119) [8]:

- Enhancing the efficiency of universities and increasing their internal and external efficiency by creating a workable environment.

- Setting laws and rules that guide the leaders and officials of universities in the administration of administrative work, so as to ensure democracy and justice for all parties concerned.

- Promote the participation of all academic and administrative members, leaders and students in decision-making processes.

- Achieving justice and equality among university workers; for high performance of all categories.

- Providing accountability and responsibility for all parties benefiting from the presence of universities.

- Achieve transparency by working in accordance with clear mechanisms and frameworks, enable employees to fully practice their work, help them to give, and actively participate in all activities within and outside universities.

It is clear from the above that university governance aims at improving financial, accounting and administrative practices in universities, in order to strengthen and stabilize the activities of university institutions and help in achieving development and stability. It also works to improve and activate performance of all kinds in university institutions, in addition to application of good morals and humanitarian dealings among those dealing with university 
institutions, as the ethical aspect of the organization's work is the most appropriate to support good and successful governance.

\subsubsection{Characteristics of University Governance}

Governance is fundamentally linked to the behavior of individuals within institutions and organizations. To achieve the purpose of applying governance, a range of characteristics that must be met in these behaviors will be explained (Al-Oraini, 2014, p. 119) [8]:

- Achieving transparency in operations and decision-making by providing a clear and real picture of what is happening within the organization.

- The possibility of assessing and evaluating the work of the Board of Directors and the executive management.

- $\quad$ Independence and avoid unnecessary influences as a result of pressure.

- Discipline and follow the proper and correct moral method.

- Social responsibility and consideration of the organization as a good individual.

- Justice and respect for the rights of all interest groups with the organization.

- Proper focus on strategic issues facing the Organization.

- Ability to separate the needs of individuals and the objectives of the organization.

It is clear from the foregoing that the above characteristics are applicable in all institutions, governmental and non-governmental organizations so that they can be used in universities and organizations of higher education, provided that the governance and principles are applied properly.

\subsubsection{Principles of University Governance}

Sticking to the principles of university governance can lead to greater understanding, sincerity, participation and confidence in processes that help in accomplishing the tasks and goals of the university. These principles are as follows:

\subsubsection{Academic Freedom}

It is a right for researchers in terms of teaching, research and publishing without censorship of the organizations they work in. Without this, the organization will not be able to play its basic roles, and it is defined as the rights of academics to define their research fields. Improving the quality of organizations, and academic freedom does not mean choosing accountability. Accountability is the other side of academic freedom; rather, accountability is the justification for giving such freedom (Dooley, 2007, p.58) [12].

\subsubsection{Transparency}

The concept of transparency refers to the freedom of access to information and the corresponding disclosure. The concept means from another public aspect, the discussion of topics and the free circulation of information on the vocabulary of work in the public domain, which means that transparency is based on the free flow of information and that organizations and community processes are opened directly. The freedom of information is not only a necessary condition for transparency, but it is also necessary to initiate accountability in order to stop acts of transgression and fraud as well as its importance to the exercise of the right to participate in decision-making (Abdul Hakim 2011, p. 320) [1].

It also means that decision-making is taken through the adoption of laws and rules through free and available information. Individuals affected by these decisions have the right to access and communicate this information. It also means that adequate information is easily supported through understandable forms and media that support communication with them (Mahmoud, 2011, p. 84) [19].

The existence of transparency and the good understanding of accounting rules can have a significant impact on improving performance in organizations of higher education. Without good information, the right decision is not possible. Higher education institutions need accurate data on teaching, research performance, student achievement, and the financial position of the institution and needs advanced information on technology that facilitates data collection and analysis, with the availability of good data that can improve decision-making, ensure that decisions are made on evidence, take a clear and understandable way for the external community. Data is necessary also for control and accountability systems which allow organizational autonomy and to improve competition and leadership levels of higher education (Miles, 2008, p. 61) [20].

The transparency of universities ensures that the University's goals are achieved to a large extent because it provides the University's members with all the data and information about it, the ways and means of decision-making, and the individuals connected with this decision. The availability of transparency achieved through the availability of such data and information would achieve a great deal of the University's goals, where everything would be declared and clear to all. Without this, there would be great difficulty in achieving the goals. Depriving various categories at the university from reviewing its performance and means of such performance which leads to low loyalty to the university and lack of desire to improve it to the required situation, in addition to the fact that the blocking of some data and information leads to the adoption of incorrect decisions, which leads to the difficulty of achieving the goals, and therefore the rules and procedures governing work should be formulated clearly, as well as the objectives of the university, budgets and inform them of individuals. 


\subsubsection{Organizational Structure}

Organizational structures are essential for all university institutions, to achieve effective oversight, transparency, and justice, at all levels. The organizational structure is the distribution of individuals in various ways among the social functions that affect the role relationships among these individuals. The organizational structure helps to implement governance, is as follows (Deboer, 2013, p.325) [11]:

- Distribution of work, responsibilities, and authorities among individuals.

- Assembling individuals in sections, sections in departments, and departments in units.

- Delegating authorities and designing procedures.

- Design of systems and means to ensure effective internal communication, the participation of individual's decision-making, interaction with the public, and the provision of good services.

- Provide the rules and means to assess the performance of employees.

\subsubsection{Accountability}

The concept of accountability refers to the existence of codified and organized methods and ways that enable the accountability of the responsible person and the control of his actions and actions in the management of his public affairs with the possibility of dismissal if the authority is exceeded or undermined the confidence of the people. This accountability is guaranteed by law and is achieved by an independent and impartial judiciary. It aims at enabling citizens and stakeholders of individuals and non-governmental organizations to monitor and hold accountable officials through appropriate channels and tools without disrupting the work. Thus, the principle of accountability is related to the need to activate the role of laws in the observation of anyone who commits a mistake or infringes on the rights of others in violation of laws and regulations (Abdul Hakim, 2011, p 320) [1]. The accountability is not only on the side of punishment but also on the existence of incentives to encourage officials to perform their duties faithfully, effectively and safely. Accountability is a cumulative responsibility. Any person who is responsible for fulfilling a duty shall be accountable for how to fulfill his responsibilities (Abdul Kareem, 2006, p. 447) [2].

Accountability is necessary to achieve transparency, demand, and need for the following (Al-Jarallah, 2010, p. 37) [6]:

- Maintaining high dependence and confidence in the work of community organizations.

- Strengthening relationships with concerned individuals, participants and others who support the organization's mission, role and existence.

- Generate greater understanding of the mission and work of organizations and how to achieve this.
- Generate greater understanding of the existence and functioning of different sectors and how they are managed, and this includes a broader understanding of political and social roles.

It is clear from the foregoing that governance provides a healthy environment that works through the principle of accountability and respect for laws and regulations and the evaluation of the performance of all in a scientific proper manner, and it works to increase confidence and promote a culture of dialogue between the different employees of the university, its leadership and students and finding formulas for dealing and interaction and integration at work and improve performance and development.

\subsubsection{Regulations and Laws}

Governance requires a fair legislative framework. It also requires full protection of the rights of individuals, especially in terms of monitoring, strengthening and enhancing laws. It also requires independent judiciary and a fair political force that does not accept bribery and characterized with justice (Mahmoud, 2011, pp. 82-83) [19].

Compliance with the rules and regulations ensures integrity and objectivity, as long as there are general rules to be invoked, and the legal framework must specify the terms of reference of each individual belonging to the University, as well as the responsibilities of the various committees and their respective roles. It should determine also the penalties that apply to individuals or some of these parties in the event of exceeding those powers or breaching their functions, as well as determining the monitoring of the application of governance procedures.

\subsubsection{Effective Participation}

Participation means participation of all parties in governance. Participation is the cornerstone of university governance. This means that the opinion of all those involved in decision-making is taken into account (Mahmoud, 2011, p. 92) [19]. The aim of participation is to bridge the gap between leadership and the public and to create non- pyramid forms to practice the power that is not based on the principle of delegation, participation and formality, but rather on the participation of the group in decision-making and its implementation (Shukr, 2005, p. 186) [23]. The participation is based on a set of specific principles as follows (Abdul Hakim, 2011, p. 321) [1]:

- Competition based on trust and mutual respect between the parties, which requires a state of law, established organizations and mature civil society.

- The independence of the parties and the full conviction that participation is the right of all parties and not a grant from the State.

- Each party has a specific and stable development strategy that includes both interim and long-term goals. 
- The existence of common ground and areas of contact between the parties and their acceptance of the idea of participation, interaction, integration and peaceful conflict.

- The prevalence of relationship of participation at all levels, from policy-making to program design and decision-making to environment preparing and implementation.

The researcher believes that strengthening the participation by the university institutions will increase the belonging and loyalty of individuals to the university institutions and make them feel their existence and their identity.

\subsubsection{Justice and Inclusiveness}

This means that the university community must ensure that all members of the university feel that they are supported feel no exclusion. This requires that all groups, especially the marginalized, find opportunities that fulfill their aspirations (Mahmoud, 2011, p. 55) [19]. The researcher believes that this principle achieves the principles related to the adoption of regulations, laws, and participation, and believes that without justice and inclusiveness, governance will not succeed in achieving its objectives.

\subsubsection{The Role of Universities in Qualifying Students to Deal with Governance}

Universities seek to train students to deal with governance, as follows:

- Formulate a clear vision and mission for the university and for each college or institute therein, so that these visions measure the degree of excellence of each college or institute with the role it is playing and seeks to achieve.

- Activating participation in the various decision-making processes by all administrative levels, reflecting the work of the team spirit within the framework of adherence to laws, legislation, regulations and university norms, leading to the proper evaluation of university performance in various fields.

- Representing the community and students in the councils of universities, colleges and institutes, in order to identify the real needs of the community and students and meet the needs of the community and the labor market in the framework of the promotion of the educational process (Khudair, 2012, p. 184) [17].

- Expanding the establishment and activation of quality centers in the colleges and institutes of the University and coordination between its various activities, so that quality is the concern of every member of the university.

- Achieve the full time of the university leaders of the faculty members and provide material support to them in order to increase loyalty to the University and work to improve it, through integration and dealing with the needs and problems of students and finding successful solutions to them.

- The governance of curricula and educational syllabus through the participation of students and faculty members of various degrees and heads of departments in the framework of access to the latest trends in education and research in various disciplines.

- Involve students effectively in the continuous evaluation of the curricula they acquired during the academic year and clarify the extent of their benefit from them, in addition to the objective survey for the assessment of teaching staff.

- Development of intellectual capital through the establishment of standards and graduated levels to achieve in terms of the quantity and quality of knowledge that must be achieved by the graduate in the public domain and in the field of cognitive specialization to which he belongs.

- Encouraging cooperation between the university and the industrial and commercial organizations in the society, as many universities seek to strengthen the relationship between them and these organizations, especially with the complexity of knowledge and the increasing volume of competition, which requires the good use of academic bodies.

- Activate the marketing of university services in various fields of consulting, research, training, and transfer of knowledge from the university departments and laboratories to the scientific application.

- $\quad$ Paying attention to the quality of knowledge, skills and trends that graduates need to meet the requirements of the labor market.

- $\quad$ Adopting the model of the productive university, a university that integrates the functions of education, research and community service to achieve some additional resources (Al-Fuqaha, 2010, p. 59) [6].

It is clear from the foregoing that this role is achieved by emphasizing the strategic role of universities in serving their society in light of local, regional and international changes. The strategic role of universities is to qualify graduates in all fields who are able to compete and deal with the knowledge society, a society in which knowledge is the main source of production, rather than capital and labor. The knowledge-based society imposes on universities, in terms of student education, attention to specialized knowledge, formation of learning organizations, teamwork, attention to survey and research skills, and attention for the continuous learning and intensive use of information technology and dealing with practical systems that simulate reality, in addition to 
hands-on training even in colleges that are called theoretical colleges. Hence, the process of teaching university students should focus on the development of thinking skills and logical analysis by dealing with different situations to make decisions in the areas of knowledge with which the university colleges and centers deal, and then the formation of concepts for students, and develop their abilities to innovate and design, the production and implementation of knowledge.

\subsection{Literature}

Al-Zahrani (2011) [9] conducted a study on the reality of application of good governance in Saudi private universities and its relation to job satisfaction and organizational loyalty of the faculty members in such universities. The study aimed to identify the reality of application of good governance in the Saudi private universities from the point of view of faculty members, and to identify the degree of job satisfaction and organizational loyalty of faculty members in Saudi private universities and to reveal the nature of the relationship between the reality of applying good governance in Saudi private universities and job satisfaction and organizational loyalty of faculty members. The study relied on the correlative descriptive approach. The study was applied to a sample of faculty members in a number of private universities and colleges in Saudi Arabia selected within the sample that amounted to 300 members. The study relied in data collection on the questionnaire. The study reached several results, the most important of which are: the Saudi private universities exercise good governance to a high extent from the point of view of faculty members. The faculty members in Saudi private universities enjoy a great degree of job satisfaction as well as a high degree of organizational loyalty.

Hafiz et al. (2012) [13] conducted a study on the use of information technology to improve the efficiency of governance of higher education institutions. The study aimed to identify the extent of benefit from using information technology to increase the efficiency of governance in organizations. The study relied on a questionnaire in obtaining research data. The College of Physical Education was chosen as a research area. The study was applied to 30 faculty members. The study concluded with a number of results, including: information technology has a significant impact on the governance of organizations and thus the success of the college and its ability to implement its plans and programs and achieve its goals and objectives efficiently and effectively. The practice of information technology in the subject college is not keeping pace with the developments and advancements that are taking place around the world, especially in the developed countries. The governance of organizations help to increase the ability of the management to control the performance of the personnel working in them, and information technology help to identify the needs of the organization of training programs and manpower development. Information technology help in information exchange processes within the organization and among all its employees.

Irtwange (2012) [16] conducted a study on the application of governance at Queen Mary College, University of London, from the point of view of teaching staff. The study aimed at identifying the reality of application of governance at Queen Mary College in London University from the point of view of faculty members. The study sample consisted of (117) members of the faculty in a simple random way. In order to collect data, a 40-point scale was used by the researcher. The results of the study indicated that the application of governance at Queen Mary College, University of London, from the point of view of the study sample as a whole was generally high.

Deboer (2013) [11] conducted a study on the importance of governance in higher education institutions, at the management colleges, Melbourne University. The study aimed to identify the importance of government in higher education institutions by applying the study to the management colleges at Melbourne University. This study was carried out through the use of case study methodology. The results of the external evaluation of administrative science programs conducted during the period January February 2013 were adopted on the field side. The study population consisted of students, staff and graduates from the departments of the Faculty of Management at Melbourne University. The study concluded with a number of results including: the level of knowledge of governance concept is very good, and there is a large proportion of the study samples in the university did not get training courses in the field of corporate governance. The study indicated also that the most important reasons for applying governance at the faculty of administration, Melbourne University (Study population) are: implementation of the regulations issued by the university management. There was a positive trend towards the implementation of governance at the university, where the most important statement that obtained high averages is that the application of governance achieves long-term goals.

Abu Kareem and Al-Thwaini (2014) [3] conducted a study on the degree of application of governance principles at the faculties of education at Hail University and King Saud University from the point of view of faculty members. The study aimed to identify the degree of application of governance principles in the faculties of education at Hail University and King Saud University from the point of view of faculty members. The study was applied to a sample of (179) members of the teaching staff. The study sample represented $23 \%$ of the total population of the study amounting 750 members. The study results showed that the faculty members of faculties of education at Hail University and King Saud believe that application of governance principles, in general, is (average). 
Halawa \& Taha (2014) [14] conducted a study on the reality of governance at Al-Quds University. The study aimed at verifying the use of university governance methods at Al-Quds University. The study indicated that the governance of Al-Quds University exists but not to the required level according to the global standards of governance, as governance tends to deal in solving problems to values and trends, rather than applying governance requirements and standards. Usually, it takes into consideration the customs and traditions in solving problems, where there are trends (parties) that play the biggest role in merging the views and solving problems, particularly if the problem is between two sides from the same party. In addition, most of the decisions are improvised, despite the existence of a book issued by the personnel affairs related to the University laws and regulations (namely: governance), but the tribal nature controls more than the use of governance systems.

Lee (2014) [18] examined how Taiwanese universities can learn from US universities in the field of governance. The study aimed to present the trends and issues of Taiwanese university governance in comparison to the governance of US universities, and draw out the applications that Taiwanese universities can benefit from American universities. The study used a descriptive analytical method. The study was applied to a sample of (130) faculty members and administrative staff. The study concluded that Taiwanese universities are ready to implement governance, noting that most universities in Taiwan adopt the model of two chambers of government, as is common in the United States, and that the university governance systems in Taiwan should be responsible for the financial and administrative affairs of the University, and that the University Council be responsible for academic matters of educational character. Therefore, governance of Taiwan universities needs more legislative changes and means of communication.
In the light of the above presentation of literature on the subject of governance in universities, it is clear that the subject of governance is of great importance, and it was noted the scarcity of studies on this subject at King Saud University. Studies in this field have focused on other universities. The researcher benefited from literature in crystallizing the study problem, developing specific themes on this subject, formulation of study methodology and determining the variables of the study, in addition to determining the appropriate statistical methods that fit with the study themes, and contribute to setting the general structure of the theoretical framework of the study.

\section{Methodological Procedures of the Study}

\subsection{Methodology}

The study is based on the descriptive method in its survey style due to its suitability for this type of study, in order to investigate the answers of a large number of the study population.

\subsection{Study Population and Sample}

The study population consists of members of the teaching staff at King Saud University. The study was limited to 430 faculty members of the theoretical colleges in the university. The theoretical colleges were chosen because their members are close to the subject of the study, especially the faculty members specialized in public administration and educational administration, business administration, education, and arts. According to Sampson equation, the sample size becomes (200) members. The following table shows the characteristics of the study sample.

Table 1. Relative distribution of the characteristics of the research sample

\begin{tabular}{|c|c|c|c|c|c|}
\hline Nationality & Frequency & Percentage & Academic qualification & Frequency & Percentage \\
\hline Saudi & 100 & $50 \%$ & PhD & 124 & $62 \%$ \\
\hline Non-Saudi & 100 & $50 \%$ & Master & 24 & $26 \%$ \\
\hline Rank & Frequency & Percentage & Other & Frequency & Percentage \\
\hline Professor & 40 & $20 \%$ & Years of experience & 48 & $24 \%$ \\
\hline Associate professor & 60 & $30 \%$ & Less than 3 years & 69 & $34 \%$ \\
\hline Asst. professor & 100 & $50 \%$ & $3-5$ years & 84 & $42 \%$ \\
\hline- & - & - & 6 years and over & & \\
\hline
\end{tabular}


Table 1 shows the relative distribution of the characteristics of the research sample. It is clear from the data in the table that $(50 \%)$ of the sample are Saudis and $(50 \%)$ are non-Saudis. The results also indicate that $(62 \%)$ of the sample of the study were Ph.D. holders and (26\%) had a master's degree. The data in the table indicated that $(50 \%)$ of the sample was an assistant professor and that the largest percentage of the sample of the study have their years of experience from (6) years and above, where they accounted for $(42 \%)$. In light of this, it can be said that the sample of the study is divided into different categories.

\subsection{Study Tool}

The researcher relied on data collection on the questionnaire, where a questionnaire was designed with several areas, according to the study questions.

\subsection{Validation of the Tool}

The researcher verified the validity of the study tool in two ways:

\subsubsection{The Apparent Validity of the Tool}

In order to determine the validity of the study tool in measuring what was set for measurement, it was presented to a number of arbitrators. The tool of this study was prepared in its final form.

\subsubsection{Internal Consistency}

The researcher calculated the internal consistency of the study tool for the paragraphs by calculating Pearson correlation coefficients between each paragraph and the total score of its areas. The following tables show correlation coefficients between the degree of each term and the total degrees of the area to which it belongs:

\subsubsection{The Consistency between the Terms and Dimensions to Which They Belong}

Table 2. Pearson correlation coefficients between the degree of each term of the study areas

\begin{tabular}{|c|c|c|c|c|c|c|c|c|c|}
\hline $\begin{array}{l}\text { Term } \\
\text { No. }\end{array}$ & $\begin{array}{c}\text { Correlation } \\
\text { coefficient }\end{array}$ & $\begin{array}{l}\text { Term } \\
\text { No. }\end{array}$ & $\begin{array}{c}\text { Correlation } \\
\text { coefficient }\end{array}$ & $\begin{array}{c}\text { Term } \\
\text { No. }\end{array}$ & $\begin{array}{c}\text { Correlation } \\
\text { coefficient }\end{array}$ & $\begin{array}{l}\text { Term } \\
\text { No. }\end{array}$ & $\begin{array}{c}\text { Correlation } \\
\text { coefficient }\end{array}$ & $\begin{array}{c}\text { Term } \\
\text { No. }\end{array}$ & $\begin{array}{c}\text { Correlation } \\
\text { coefficient }\end{array}$ \\
\hline \multicolumn{2}{|c|}{ Transparency } & \multicolumn{2}{|c|}{ Accountability } & \multicolumn{2}{|c|}{ Organizational structure } & \multicolumn{2}{|c|}{ Regulations \& laws } & \multicolumn{2}{|c|}{ Justice } \\
\hline 1 & $0.84 * *$ & 1 & $0.80 * *$ & 1 & $0.81 * *$ & 1 & $0.77 * *$ & 1 & $0.89 * *$ \\
\hline 2 & $0.72 * *$ & 2 & $0.86 * *$ & 2 & $0.84 * *$ & 2 & $0.78 * *$ & 2 & $0.92 * *$ \\
\hline 3 & $0.88 * *$ & 3 & $0.88 * *$ & 3 & $0.87 * *$ & 3 & $0.91 * *$ & 3 & $0.90 * *$ \\
\hline 4 & $0.85 * *$ & 4 & $0.90 * *$ & 4 & $0.89 * *$ & 4 & $0.85 * *$ & 4 & $0.86 * *$ \\
\hline 5 & $0.76 * *$ & 5 & $0.93 * *$ & 5 & $0.83 * *$ & 5 & $0.90 * *$ & 5 & $0.87 * *$ \\
\hline 6 & $0.70 * *$ & 6 & $0.84 * *$ & 6 & $0.69 * *$ & 6 & $0.71 * *$ & - & - \\
\hline 7 & $0.75 * *$ & 7 & $0.81 * *$ & - & - & - & - & - & - \\
\hline 8 & $0.72 * *$ & - & - & - & - & - & - & - & - \\
\hline 9 & $0.83 * *$ & - & - & - & - & - & - & - & - \\
\hline
\end{tabular}

** Significant at the level of significance 0.01 and less

It is clear from the above table 2 that correlation coefficients of the degree of each statement with the dimension to which it belongs are of high values, indicating that each of the area statements is associated with the dimension to which it belongs, indicating the consistency of the terms of each dimension of the questionnaire.

\subsection{Stability of the Tool}

To verify the stability of the questionnaire, the researcher used the Alpha Cronbach coefficient. The following table shows the stability coefficients produced using this equation.

Table 3. Stability coefficients of the search tool according to its different areas

\begin{tabular}{|c|c|c|}
\hline Areas & No. of statements & Stability coefficient \\
\hline Transparency & 9 & 0.768 \\
\hline Accountability & 7 & 0.777 \\
\hline Organizational structure & 6 & 0.785 \\
\hline Regulations and laws & 6 & 0.789 \\
\hline Justice & 5 & 0.796 \\
\hline The tool as a whole & 33 & 0.915 \\
\hline
\end{tabular}


The above table shows that the values of all stability coefficients are high. The high values of stability coefficients in the table indicate the validity of the questionnaire for the application and the reliability and trust of its results.

\subsection{Statistical Processing Methods}

To achieve the objectives of the study and analyze the data collected, various appropriate statistical methods were used using the statistical package for social sciences (SPSS).

\section{Study Results}

The following tables illustrate the degree of application of governance requirements at King Saud University from the point of view of faculty members through transparency, accountability, organizational structure, laws and regulations, and justice.

Table 4. Transparency

\begin{tabular}{|c|c|c|c|c|c|c|c|c|c|c|}
\hline No & \multicolumn{2}{|l|}{ Statements } & $\begin{array}{l}\text { At very } \\
\text { high } \\
\text { degree }\end{array}$ & $\begin{array}{c}\text { At } \\
\text { high } \\
\text { degree }\end{array}$ & $\begin{array}{c}\text { At } \\
\text { average } \\
\text { degree } \\
\end{array}$ & $\begin{array}{l}\text { At low } \\
\text { degree }\end{array}$ & $\begin{array}{c}\text { At very } \\
\text { low } \\
\text { degree }\end{array}$ & $\begin{array}{l}\text { Arithmetic } \\
\text { mean }\end{array}$ & $\begin{array}{l}\text { Standard } \\
\text { deviation }\end{array}$ & Order \\
\hline \multirow[b]{2}{*}{1} & \multirow{2}{*}{$\begin{array}{l}\text { The university is committed } \\
\text { to the right of the concerned } \\
\text { to access the required } \\
\text { information }\end{array}$} & $\mathrm{K}$ & 32 & 56 & 92 & 12 & 8 & \multirow[b]{2}{*}{3.46} & \multirow[b]{2}{*}{0.96} & \multirow[b]{2}{*}{4} \\
\hline & & $\%$ & 16.0 & 28.0 & 46.0 & 6.0 & 4.0 & & & \\
\hline \multirow[b]{2}{*}{2} & \multirow{2}{*}{$\begin{array}{l}\text { The university will allow the } \\
\text { concerned authorities to } \\
\text { access and follow up its } \\
\text { performance }\end{array}$} & $\mathrm{K}$ & 32 & 56 & 76 & 24 & 12 & \multirow[b]{2}{*}{3.36} & \multirow[b]{2}{*}{1.0} & \multirow[b]{2}{*}{5} \\
\hline & & $\%$ & 16.0 & 28.0 & 38.0 & 12.0 & 6.0 & & & \\
\hline \multirow[b]{2}{*}{3} & \multirow{2}{*}{$\begin{array}{l}\text { The University is interested in } \\
\text { updating the procedural } \\
\text { manuals of work to remove } \\
\text { any ambiguity }\end{array}$} & $\mathrm{K}$ & 32 & 64 & 60 & 28 & 16 & \multirow[b]{2}{*}{3.34} & \multirow[b]{2}{*}{1.14} & \multirow[b]{2}{*}{6} \\
\hline & & $\%$ & 16.0 & 32.0 & 30.0 & 14.0 & 8.0 & & & \\
\hline \multirow[b]{2}{*}{4} & \multirow{2}{*}{$\begin{array}{l}\text { The University is committed } \\
\text { to disclosing the details of the } \\
\text { expenditure items with } \\
\text { utmost accuracy and clarity }\end{array}$} & $\mathrm{K}$ & 32 & 52 & 64 & 28 & 24 & \multirow[b]{2}{*}{3.20} & \multirow[b]{2}{*}{1.2} & \multirow[b]{2}{*}{8} \\
\hline & & $\%$ & 16.0 & 26.0 & 32.0 & 14.0 & 12.0 & & & \\
\hline \multirow[b]{2}{*}{5} & \multirow{2}{*}{$\begin{array}{l}\text { The University is committed } \\
\text { to providing the necessary } \\
\text { evidence to inform the } \\
\text { concerned with the } \\
\text { educational services provided }\end{array}$} & $\mathrm{K}$ & 40 & 68 & 64 & 20 & 8 & \multirow[b]{2}{*}{3.56} & \multirow[b]{2}{*}{1.0} & \multirow[b]{2}{*}{1} \\
\hline & & $\%$ & 20.0 & 34.0 & 32.0 & 10.0 & 4.0 & & & \\
\hline \multirow[b]{2}{*}{6} & \multirow{2}{*}{$\begin{array}{c}\text { The university is not sensitive } \\
\text { towards the media when } \\
\text { publishing cases of } \\
\text { corruption, if any }\end{array}$} & $\mathrm{K}$ & 24 & 44 & 84 & 28 & 20 & \multirow[b]{2}{*}{3.12} & \multirow[b]{2}{*}{1.11} & \multirow[b]{2}{*}{9} \\
\hline & & $\%$ & 12.0 & 22.0 & 42.0 & 14.0 & 10.0 & & & \\
\hline \multirow[b]{2}{*}{7} & \multirow{2}{*}{$\begin{array}{l}\text { Employment policies are } \\
\text { based on competency, merit } \\
\text { and in accordance with } \\
\text { specific and declared } \\
\text { standards }\end{array}$} & $\mathrm{K}$ & 32 & 88 & 48 & 8 & 24 & \multirow[b]{2}{*}{3.48} & & \\
\hline & & $\%$ & 16.0 & 44.0 & 24.0 & 4.0 & 12.0 & & 1.17 & 3 \\
\hline & Promotion policies are built & $\mathrm{K}$ & 36 & 84 & 52 & 12 & 16 & & & \\
\hline 8 & $\begin{array}{l}\text { on competency, merit and } \\
\text { specific and declared } \\
\text { standards. }\end{array}$ & $\%$ & 18.0 & 42.0 & 26.0 & 6.0 & 8.0 & 3.56 & 1.1 & 2 \\
\hline & Information is available at the & $\mathrm{K}$ & 40 & 52 & 48 & 48 & 12 & & & \\
\hline 9 & $\begin{array}{l}\text { university immediately when } \\
\text { needed }\end{array}$ & $\%$ & 20.0 & 26.0 & 24.0 & 24.0 & 6.0 & 3.30 & 1.2 & 7 \\
\hline & & & ransparen & & & & & 3.37 & 1.0 & \\
\hline
\end{tabular}


The data in the previous table 4 indicate that the general arithmetic mean of the area was (3.37), which indicates the tendency of the responses of the study sample to "Average" on the statements in the area. This indicates that the level of transparency at the university is average.

In the first order, (the university is committed to providing the necessary evidence to inform those involved with the educational services provided by it). The mean was (3.56) and the standard deviation is (1.0). The percentage of those who answered with a very high degree was $(20 \%)$, and the percentage of those who answered with high degree was (34\%).

In the second order came the statement (promotion policies are based on efficiency, merit, and specific criteria), the average was (3.56) and the standard deviation was 1.1. The percentage of those who answered with very high was (18\%) and those who responded with a high score (42\%). The third order was for the term: (the employment policies are based on efficiency, merit and according to specific and declared criteria). The mean was (3.48) and the standard deviation (1.17). The percentage of respondents with very high was $(16 \%)$, and the percentage of those who answered with a high degree was (44\%). In the ninth and last order, the statement came as follows: (The University is not sensitive towards the media when publishing corruption cases if any). The mean was (3.12) and the standard deviation is (1.11). The percentage of those who responded with very high was $(12 \%)$, and the percentage of those who responded with a high degree was $(22 \%)$.

Table (5) shows the frequency, percentages, arithmetical means and standard deviations of the sample responses on the elements of the accountability area. The data in the table indicate that the general mean of the area was (3.16), indicating the tendency of the sample responses to (Average) on the statements of the area, and that indicates that the level of accountability at the university is average.

Table 5. Accountability

\begin{tabular}{|c|c|c|c|c|c|c|c|c|c|c|}
\hline No. & \multicolumn{2}{|l|}{ Statements } & $\begin{array}{c}\text { At very } \\
\text { high } \\
\text { degree }\end{array}$ & $\begin{array}{l}\text { At high } \\
\text { degree }\end{array}$ & $\begin{array}{c}\text { At } \\
\text { average } \\
\text { degree }\end{array}$ & $\begin{array}{l}\text { At low } \\
\text { degree }\end{array}$ & $\begin{array}{l}\text { At very } \\
\text { low } \\
\text { degree }\end{array}$ & $\begin{array}{l}\text { Arithmetic } \\
\text { mean }\end{array}$ & $\begin{array}{l}\text { Standard } \\
\text { deviation }\end{array}$ & Order \\
\hline \multirow[b]{2}{*}{1} & \multirow{2}{*}{$\begin{array}{l}\text { The University is } \\
\text { committed to the right of } \\
\text { community organizations } \\
\text { and the media to monitor } \\
\text { their performance. }\end{array}$} & $\mathrm{K}$ & 8 & 64 & 96 & 20 & 12 & \multirow[b]{2}{*}{3.18} & \multirow[b]{2}{*}{0.89} & \multirow[b]{2}{*}{3} \\
\hline & & $\%$ & 4.0 & 32.0 & 48.0 & 10.0 & 6.0 & & & \\
\hline \multirow[b]{2}{*}{2} & \multirow{2}{*}{$\begin{array}{l}\text { The university obliges its } \\
\text { employees to provide } \\
\text { explanations for their } \\
\text { doubtful decisions. }\end{array}$} & $\mathrm{K}$ & 8 & 56 & 96 & 16 & 24 & \multirow[b]{2}{*}{3.04} & \multirow[b]{2}{*}{1.00} & \multirow[b]{2}{*}{7} \\
\hline & & $\%$ & 4.0 & 28.0 & 48.0 & 8.0 & 12 & & & \\
\hline \multirow[b]{2}{*}{3} & \multirow{2}{*}{$\begin{array}{l}\text { Supervisory bodies shall } \\
\text { have sufficient powers at } \\
\text { the University. }\end{array}$} & $\mathrm{K}$ & 32 & 52 & 72 & 20 & 24 & \multirow{2}{*}{3.24} & \multirow{2}{*}{1.19} & \multirow{2}{*}{2} \\
\hline & & $\%$ & 16.0 & 29.0 & 36.0 & 10.0 & 12.0 & & & \\
\hline \multirow[b]{2}{*}{4} & \multirow{2}{*}{$\begin{array}{l}\text { The Supervisory bodies } \\
\text { have channels to receive } \\
\text { reports of any } \\
\text { irregularities. }\end{array}$} & $\mathrm{K}$ & 32 & 56 & 56 & 28 & 28 & \multirow[b]{2}{*}{3.18} & \multirow[b]{2}{*}{1.24} & \multirow[b]{2}{*}{4} \\
\hline & & $\%$ & 16.0 & 28.0 & 28.0 & 14.0 & 14.0 & & & \\
\hline \multirow[b]{2}{*}{5} & \multirow{2}{*}{$\begin{array}{l}\text { The University has } \\
\text { information that can be } \\
\text { used to measure } \\
\text { adherence to the } \\
\text { University's goals. }\end{array}$} & $\mathrm{K}$ & 16 & 76 & 72 & 20 & 16 & \multirow[b]{2}{*}{3.28} & \multirow[b]{2}{*}{1.02} & \multirow[b]{2}{*}{1} \\
\hline & & $\%$ & 8.0 & 38.0 & 36.0 & 10 & 8.0 & & & \\
\hline \multirow[b]{2}{*}{6} & \multirow{2}{*}{$\begin{array}{l}\text { The University has a } \\
\text { system that defines the } \\
\text { nature and form of } \\
\text { accountability. }\end{array}$} & $\mathrm{K}$ & 16 & 60 & 68 & 32 & 24 & \multirow[b]{2}{*}{3.06} & \multirow[b]{2}{*}{1.12} & \multirow[b]{2}{*}{6} \\
\hline & & $\%$ & 8.0 & 30.0 & 34.0 & 16.0 & 12.0 & & & \\
\hline \multirow[b]{2}{*}{7} & \multirow{2}{*}{$\begin{array}{l}\text { The University is } \\
\text { interested in the } \\
\text { development of self-audit } \\
\text { of its employees. }\end{array}$} & $\mathrm{K}$ & 36 & 48 & 60 & 24 & 32 & \multirow[b]{2}{*}{3.16} & \multirow[b]{2}{*}{1.13} & \multirow[b]{2}{*}{5} \\
\hline & & $\%$ & 18.0 & 24.0 & 30.0 & 12.0 & 16.0 & & & \\
\hline & & & Accounta & lity & & & & 3.16 & 1.00 & \\
\hline
\end{tabular}


In the first order, came the statement: (the university has the information that can be used to measure the extent of commitment with the University's goals). The mean was (3.28) and the standard deviation (1.0). The percentage of those who answered with very high was $(8 \%)$, and the percentage of those who answered with High was (38\%).

In the second order, came the statement: (the supervisory bodies shall have sufficient powers at the university). The mean was (3.23) and standard deviation (1.19). The percentage of those who answered with very high was $(16 \%)$, and the percentage of those who responded with high was (26\%).

In the third order, came the statement: (The University is committed to the right of community organizations and the media to monitor their performance). The mean was (3.18) and the standard deviation (0.89). The percentage of those who answered was very high (4\%), and those who responded to a high degree (32\%). In the seventh and last rank, the statement: (the university obligates its employees to provide explanations for their doubtful decisions). The arithmetic mean was (3.04) and the standard deviation is (1.0). The percentage of those who answered very high (4\%), and those who answered with high was (28\%).

Table (6) shows the frequency, percentages, arithmetical means and standard deviations of the sample responses on the statements of the organizational structure area. The data in the table indicate that the general mean of the area was (3.45), indicating the tendency of the sample responses to "high" on the statements of the area, and this indicates that the level of organizational structure at the university is high.

In the first order, came the statement: (The University's admission and registration policies are clear). The mean was (4.02) and the standard deviation was (1.0). The percentage of those who answered with very high was $(42 \%)$, and those who answered with a high degree was $(32 \%)$.

In the second order, came the statement: (The organizational structure of the university is clear enough). The mean was (3.98) and the standard deviation was (1.0). The percentage of those who answered with very high was $(42 \%)$, and the percentage of those who responded with high was (28\%).

In the third order came the statement: (The leaders of the university are keen to study and solve the complaints of workers.). The mean was (3.56) and the standard deviation was (1.1). The percentage of those who responded with very high was $(26 \%)$, and the percentage of those who responded with high was $(28 \%)$.

In the sixth and final order, the statement: "Faculty members participate in the selection of academic leaders." The mean was (2.76) and the standard deviation was (1.3). The percentage of respondents who answered with very high was (12\%), and those who responded with high was $(20 \%)$.

Table 6. Organizational Structure

\begin{tabular}{|c|c|c|c|c|c|c|c|c|c|c|}
\hline No. & \multicolumn{2}{|l|}{ Statements } & $\begin{array}{l}\text { At very } \\
\text { high } \\
\text { degree }\end{array}$ & $\begin{array}{l}\text { At high } \\
\text { degree }\end{array}$ & $\begin{array}{c}\text { At } \\
\text { average } \\
\text { degree }\end{array}$ & $\begin{array}{l}\text { At low } \\
\text { degree }\end{array}$ & $\begin{array}{l}\text { At very } \\
\text { low } \\
\text { degree }\end{array}$ & $\begin{array}{l}\text { Arithmetic } \\
\text { mean }\end{array}$ & $\begin{array}{l}\text { Standard } \\
\text { deviation }\end{array}$ & Order \\
\hline \multirow[b]{2}{*}{1} & \multirow{2}{*}{$\begin{array}{l}\text { The organizational } \\
\text { structure of the } \\
\text { university is clear } \\
\text { enough. }\end{array}$} & $\mathrm{K}$ & 84 & 56 & 36 & 20 & 4 & \multirow[b]{2}{*}{3.98} & \multirow[b]{2}{*}{1.0} & \multirow[b]{2}{*}{2} \\
\hline & & $\%$ & 42.0 & 28.0 & 18.0 & 10.0 & 2.0 & & & \\
\hline \multirow[b]{2}{*}{2} & \multirow{2}{*}{$\begin{array}{l}\text { The University's } \\
\text { admission and } \\
\text { registration policies are } \\
\text { clear. }\end{array}$} & $\mathrm{K}$ & 84 & 64 & 32 & 12 & 8 & \multirow[b]{2}{*}{4.02} & \multirow[b]{2}{*}{1.0} & \multirow[b]{2}{*}{1} \\
\hline & & $\%$ & 42.0 & 32.0 & 16.0 & 6.0 & 4.0 & & & \\
\hline \multirow[b]{2}{*}{3} & \multirow{2}{*}{$\begin{array}{l}\text { The university leaders } \\
\text { are keen to study and } \\
\text { solve complaints of the } \\
\text { staff. }\end{array}$} & $\mathrm{K}$ & 52 & 56 & 56 & 24 & 12 & \multirow[b]{2}{*}{3.56} & \multirow[b]{2}{*}{1.1} & \multirow[b]{2}{*}{3} \\
\hline & & $\%$ & 26.0 & 28.0 & 28.0 & 12.0 & 6.0 & & & \\
\hline \multirow[b]{2}{*}{4} & \multirow{2}{*}{$\begin{array}{l}\text { The university has } \\
\text { scientific standards } \\
\text { for the selection of } \\
\text { administrative } \\
\text { leaders. }\end{array}$} & $\mathrm{K}$ & 36 & 64 & 40 & 36 & 24 & \multirow[b]{2}{*}{3.26} & \multirow[b]{2}{*}{1.2} & \multirow[b]{2}{*}{4} \\
\hline & & $\%$ & 18.0 & 32.0 & 20.0 & 18.0 & 12.0 & & & \\
\hline \multirow{2}{*}{5} & \multirow{2}{*}{$\begin{array}{l}\text { The University applies a } \\
\text { democratic leadership } \\
\text { style. }\end{array}$} & $\mathrm{K}$ & 24 & 64 & 52 & 32 & 28 & \multirow{2}{*}{3.12} & \multirow{2}{*}{1.2} & \multirow{2}{*}{5} \\
\hline & & $\%$ & 12.0 & 32.0 & 26.0 & 16.0 & 14.0 & & & \\
\hline \multirow[b]{2}{*}{6} & \multirow{2}{*}{$\begin{array}{c}\text { Faculty members } \\
\text { participate in the } \\
\text { selection of academic } \\
\text { leaders. }\end{array}$} & $\mathrm{K}$ & 24 & 40 & 40 & 56 & 40 & \multirow[b]{2}{*}{2.76} & \multirow[b]{2}{*}{1.3} & \multirow[b]{2}{*}{6} \\
\hline & & $\%$ & 12.0 & 20.0 & 20.0 & 28.0 & 20.0 & & & \\
\hline \multicolumn{8}{|c|}{ Organizational Structure } & 3.45 & \multicolumn{2}{|c|}{1.9} \\
\hline
\end{tabular}


Table 7 shows the frequencies, percentages, arithmetic mean, and standard deviations of the sample responses on the statements of the areas of regulations and laws. The data in the table indicate that the general mean of the area was (3.54), indicating the tendency of the sample responses to "High" on the area statements, and this indicates that the level of regulations and laws at the university is high.

In the first order, the term (the guidelines include the admission and registration policies according to the approved criteria), the mean was (3.94) and the standard deviation (1.1). The percentage of respondents who answered with very high was (38\%), and those answered with high was (34\%).

In the second order, the term (regulations and laws are available on the university's website), the mean was (3.92) and the standard deviation (1.1). The percentage of those who responded with very high was (34\%), and the percentage of those who answered with a high degree was $(36 \%)$.

In the third order, the term (the regulations and laws at the university ensure easy flow of information), the mean was (3.48) and standard deviation (1.1). The percentage of those who answered with very high was $(16 \%)$, and the percentage of those who responded with a high degree was $(38 \%)$.

In the sixth and final order, the term (A technical guide is available in each section). The mean was (3.16), and the standard deviation is (1.2). The percentage of those who responded with very high was (14\%), and the percentage of those who responded with a high degree was $(28 \%)$.

Table 7. Regulations and laws

\begin{tabular}{|c|c|c|c|c|c|c|c|c|c|c|}
\hline No. & \multicolumn{2}{|l|}{ Statements } & $\begin{array}{l}\text { At very } \\
\text { high } \\
\text { degree }\end{array}$ & $\begin{array}{l}\text { At high } \\
\text { degree }\end{array}$ & $\begin{array}{c}\text { At } \\
\text { average } \\
\text { degree }\end{array}$ & $\begin{array}{l}\text { At low } \\
\text { degree }\end{array}$ & $\begin{array}{c}\text { At very } \\
\text { low } \\
\text { degree }\end{array}$ & $\begin{array}{l}\text { Arithmetic } \\
\text { mean }\end{array}$ & $\begin{array}{l}\text { Standard } \\
\text { deviation }\end{array}$ & Order \\
\hline \multirow{2}{*}{1} & \multirow{2}{*}{$\begin{array}{l}\text { Regulations and laws are } \\
\text { available on the } \\
\text { university website. }\end{array}$} & $\mathrm{K}$ & 68 & 72 & 40 & 16 & 4 & \multirow{2}{*}{3.92} & \multirow{2}{*}{1.0} & \multirow{2}{*}{2} \\
\hline & & $\%$ & 34.0 & 36.0 & 20.0 & 8.0 & 2.0 & & & \\
\hline \multirow[b]{2}{*}{2} & \multirow{2}{*}{$\begin{array}{l}\text { The guidelines include } \\
\text { admission and } \\
\text { registration policies in } \\
\text { accordance with } \\
\text { approved criteria. }\end{array}$} & $\mathrm{K}$ & 76 & 68 & 36 & 8 & 12 & \multirow[b]{2}{*}{3.94} & \multirow[b]{2}{*}{1.1} & \multirow[b]{2}{*}{1} \\
\hline & & $\%$ & 38.0 & 34.0 & 18.0 & 4.0 & 6.0 & & & \\
\hline \multirow{2}{*}{3} & \multirow{2}{*}{$\begin{array}{l}\text { University regulations } \\
\text { and laws support } \\
\text { transparency. }\end{array}$} & $\mathrm{K}$ & 36 & 80 & 40 & 28 & 16 & \multirow{2}{*}{3.46} & \multirow{2}{*}{1.17} & \multirow{2}{*}{4} \\
\hline & & $\%$ & 18.0 & 40.0 & 20.0 & 14.0 & 8.0 & & & \\
\hline \multirow[b]{2}{*}{4} & \multirow{2}{*}{$\begin{array}{l}\text { University regulations } \\
\text { and laws ensure easy } \\
\text { flow of information. }\end{array}$} & $\mathrm{K}$ & 32 & 76 & 56 & 28 & 8 & \multirow[b]{2}{*}{3.48} & \multirow[b]{2}{*}{1.0} & \multirow[b]{2}{*}{3} \\
\hline & & $\%$ & 16.0 & 38.0 & 28.0 & 14.0 & 4.0 & & & \\
\hline \multirow[b]{2}{*}{5} & \multirow{2}{*}{$\begin{array}{l}\text { Regulations and laws } \\
\text { achieve a high degree of } \\
\text { administrative } \\
\text { effectiveness. }\end{array}$} & $\mathrm{K}$ & 24 & 56 & 84 & 24 & 12 & \multirow[b]{2}{*}{3.28} & \multirow[b]{2}{*}{1.0} & \multirow[b]{2}{*}{5} \\
\hline & & $\%$ & 12.0 & 28.0 & 42.0 & 12.0 & 6.0 & & & \\
\hline \multirow{2}{*}{6} & \multirow{2}{*}{$\begin{array}{c}\text { A technical guide is } \\
\text { available in each section. }\end{array}$} & $\mathrm{K}$ & 28 & 56 & 60 & 32 & 24 & \multirow{2}{*}{3.16} & \multirow{2}{*}{1.2} & \multirow{2}{*}{6} \\
\hline & & $\%$ & 14.0 & 28.0 & 30.0 & 16.0 & 12.0 & & & \\
\hline \multicolumn{8}{|c|}{ Regulations and laws } & 3.54 & \multicolumn{2}{|c|}{0.91} \\
\hline
\end{tabular}

Table 8. Justice

\begin{tabular}{|c|c|c|c|c|c|c|c|c|c|c|}
\hline No. & \multicolumn{2}{|l|}{ Statements } & $\begin{array}{l}\text { At very } \\
\text { high } \\
\text { degree }\end{array}$ & $\begin{array}{l}\text { At high } \\
\text { degree }\end{array}$ & $\begin{array}{c}\text { At } \\
\text { average } \\
\text { degree }\end{array}$ & $\begin{array}{l}\text { At low } \\
\text { degree }\end{array}$ & $\begin{array}{c}\text { At very } \\
\text { low } \\
\text { degree }\end{array}$ & $\begin{array}{c}\text { Arithmetic } \\
\text { mean }\end{array}$ & $\begin{array}{l}\text { Standard } \\
\text { deviation }\end{array}$ & Order \\
\hline \multirow[b]{2}{*}{1} & \multirow{2}{*}{$\begin{array}{l}\text { The University has a fair } \\
\text { system of incentives and } \\
\text { rewards. }\end{array}$} & $\mathrm{K}$ & 32 & 68 & 36 & 28 & 36 & \multirow[b]{2}{*}{3.16} & \multirow[b]{2}{*}{1.3} & \multirow[b]{2}{*}{4} \\
\hline & & $\%$ & 16.0 & 34.0 & 18.0 & 14.0 & 18.0 & & & \\
\hline \multirow{2}{*}{2} & \multirow{2}{*}{$\begin{array}{c}\text { Decisions are applied to } \\
\text { everyone without } \\
\text { exception. }\end{array}$} & $\mathrm{K}$ & 40 & 52 & 44 & 20 & 44 & \multirow{2}{*}{3.14} & \multirow{2}{*}{1.4} & \multirow[b]{2}{*}{5} \\
\hline & & $\%$ & 20.0 & 26.0 & 22.0 & 10.0 & 22.0 & & & \\
\hline \multirow{2}{*}{3} & \multirow{2}{*}{$\begin{array}{l}\text { Decisions at work are } \\
\text { taken without prejudice. }\end{array}$} & $\mathrm{K}$ & 44 & 64 & 36 & 20 & 36 & \multirow{2}{*}{3.30} & \multirow{2}{*}{1.3} & \multirow{2}{*}{2} \\
\hline & & $\%$ & 22.0 & 32.0 & 18.0 & 10.0 & 18.0 & & & \\
\hline \multirow{2}{*}{4} & \multirow{2}{*}{$\begin{array}{l}\text { The additional workload } \\
\text { is equally distributed } \\
\text { among faculty members. }\end{array}$} & $\mathrm{K}$ & 32 & 60 & 48 & 28 & 32 & \multirow[b]{2}{*}{3.16} & \multirow[b]{2}{*}{1.3} & \multirow[b]{2}{*}{3} \\
\hline & & $\%$ & 16 & 30.0 & 24.0 & 14.0 & 16.0 & & & \\
\hline \multirow[b]{2}{*}{5} & \multirow{2}{*}{$\begin{array}{l}\text { Performance is evaluated } \\
\text { according to fair } \\
\text { standards. }\end{array}$} & $\mathrm{K}$ & 36 & 76 & 48 & 12 & 28 & \multirow[b]{2}{*}{3.40} & \multirow[b]{2}{*}{1.2} & \multirow[b]{2}{*}{1} \\
\hline & & $\%$ & 18.0 & 38.0 & 24.0 & 6.0 & 14.0 & & & \\
\hline \multicolumn{8}{|c|}{ Justice } & 3.22 & \multicolumn{2}{|c|}{0.91} \\
\hline
\end{tabular}


Table 8 shows the frequencies, percentages, arithmetic mean, and standard deviations of the sample responses on the statements of justice area. The data in the table indicate that the general mean of the area was (3.22), indicating the tendency of the sample responses to (Average) on the area statements, and this indicates that the level of justice at the university is average.

In the first order, the term (Performance is evaluated according to fair standards), the mean was (3.40) and the standard deviation (1.2). The percentage of respondents who answered with very high was $(18 \%)$, and those answered with high was (38\%).

In the second order, the term (Decisions at work are taken without prejudice.), the mean was (3.30) and the standard deviation (1.3). The percentage of respondents who answered with very high was $(22 \%)$, and those answered with high was (32\%).

In the third order was the term: (The volume of additional workload is equally distributed among the faculty members). The mean was (3.16) and the standard deviation (1.3). The percentage of respondents who answered with very high was $(16 \%)$, and those answered with high was $(30 \%)$. In the fifth and final order, the statement (Decisions are applied to everyone without exception), the mean was (3.14) and the standard deviation (1.4). The percentage of respondents who answered with very high was $(20 \%)$, and those answered with high was $(26 \%)$

Table 9. Degree of application of the requirements of governance at King Saud University as seen by the faculty members in a descending order according to the value of the arithmetic mean

\begin{tabular}{|c|c|c|c|c|}
\hline $\begin{array}{c}\text { Dimensions of } \\
\text { Governance }\end{array}$ & $\begin{array}{c}\text { Arithmetic } \\
\text { Mean }\end{array}$ & $\begin{array}{c}\text { Standard } \\
\text { Deviation }\end{array}$ & Degree & Order \\
\hline Transparency & 3.37 & 1.0 & Average & 3 \\
\hline Accountability & 3.16 & 1.00 & Average & 5 \\
\hline $\begin{array}{c}\text { Organizational } \\
\text { Structure }\end{array}$ & 3.45 & 1.9 & High & 2 \\
\hline $\begin{array}{c}\text { Regulations and } \\
\text { laws }\end{array}$ & 3.54 & 0.91 & High & 1 \\
\hline Justice & 3.22 & 0.91 & Average & 4 \\
\hline General index & 3.35 & 1.14 & \multicolumn{2}{|c|}{ Average } \\
\hline
\end{tabular}

It is clear from the above table that the area of regulations and laws came in the first order with a mean of (3.54) and a standard deviation of (0.91) followed by the organizational structure area with a mean of (3.45) and a standard deviation of (1.9). The third order was for transparency area with a mean of (3.37) and a standard deviation of (1.0). In the fourth order, the area of justice was represented by a mean of (3.22) and a standard deviation of (0.91). In the fifth and final order, the accountability area mean was (3.16) and a standard deviation of (1.0).

The general arithmetical mean for the areas of application of governance requirements was (3.35) in the third category of the five-step scale, indicating an average agreement on the items of the area.

\section{Discussion of Results and Recommendations}

\subsection{Discussion of Results}

The study reached several conclusions concerning the degree of application of governance requirements at King Saud University from the point of view of faculty members that can be summarized as follows:

- The general arithmetic mean of the transparency area was (3.37), indicating the tendency of the responses of the sample of the study to "Average" on the statements of the area. This indicates that the level of transparency in the university is average.

As mentioned earlier, the availability of transparency in universities guarantees the achievement of the University's goals to a large extent, because it provides the university members with all the data and information about the university, the means and mechanisms of decision-making therein, and the staff related with these decisions. Availability of transparency also achieves a great deal of the University's goals, where everything is declared and visible to all members, contributing to the application of governance.

- The general arithmetical mean of the accountability area was (3.16), which indicates that the responses of the sample of the study is "Average" on the statements in the area, indicating that the level of accountability at the university is average.

No doubt that accountability is of great importance in terms of its contribution to the follow-up of those responsible for the educational process at the university and to assess the level of their performance, and reward those showing excellent performance within the educational and administrative staff.

- The general arithmetic mean of the area of organizational structure was (3.45), indicating the tendency of the responses of the sample of the study to "High" on the statements in the area. This indicates that the level of the organizational structure of the university is high. The organizational structure is very important as it is the identifier of the authority and responsibility lines, the relations among the different departments, the culture of communication lines and their patterns, the way individuals work and their role in the organization, as well as the prevailing culture among individuals about the nature of relations among them.

The organizational structure includes several factors, including follow-up of progress towards emergency preparedness, the willingness of individuals to teamwork, the distribution and knowledge of tasks and roles, the belief in the importance of training, continuation of education and the stability of objectives. 
- The general arithmetic mean of the area of regulations and laws was (3.54), which indicates the tendency of responses of the study sample to "High" on the statements in the area, indicating that the level of regulations and laws at the university is high.

This result is positive because the laws and regulations obtained a high degree, which contributes to the application of governance at the university.

- The general arithmetic mean of the area of justice was (3.22), which indicates the tendency of responses of the sample of the study to "Average" on the statements in the area. This indicates that the level of justice at the university is average.

In light of this result, it can be said that the variable of justice needs support at King Saud University, where its result was average. Also, it could be concluded that the result reached is positive and indicates the possibility of implementing governance at King Saud University. Within this field, Hafiz et al. (2012) [13] concluded that governance helps organizations increase the ability of management to control the performance of their staff. The findings also indicate that corporate governance helps to increase the management's ability to control the performance of its staff. This result is in line with the findings of Abu Kareem and Al-Thwaini (2014) [3], whose findings show that application of the principles of governance, in general, is average. Halawa and Taha (2014) [14] concluded that governance at Al-Quds University exists but is not at the required level.

Deboer (2013) [11], concluded that there is a positive trend towards the implementation of governance at the university. Halawa and Taha (2014) [14], concluded that the governance of Al-Quds University exists but not to the required level. Lee (2014) [18] concluded that the Taiwanese universities are ready to implement governance. This result differs from the study of Al-Zahrani (2011) [9], which concluded that the private universities in Saudi Arabia exercise governance at a high degree from the point of view of the faculty members. It also differs from Irtwange (2012) [16] study which concluded that the reality of applying governance at Queen Mary College, University of London, was generally high.

\subsection{Recommendations}

In the light of the results of the present study, the researcher suggests some recommendations:

1. The results showed that the statement of the sensitivity of the university towards the media when publishing corruption cases came in the last order. Therefore, the researcher recommends that King Saud University should avoid sensitivity towards the media when publishing corruption cases, if any.
2. The results indicate that the statement of the university obliging its staff to provide explanations on their doubtful decisions came in the seventh and final order in the results of the study. Therefore, the researcher recommends that the university oblige its employees to provide explanations on their doubtful decisions.

3. The results show that the statement regarding the participation of faculty members in the selection of academic leaders obtained the last ranking with a low mean. Therefore, the researcher recommends that the university administration should be interested in the participation of faculty members in the selection of academic leaders.

4. The results showed that the statement on the availability of a technical guide in each department of the university came in the last order. Therefore, the researcher recommends that the university should provide a technical guide in each department within the university.

5. It is clear from the results that the statement concerning the application of decisions to all members without exception came in the last order. Therefore, the researcher recommends that the decisions of the university be applied to everyone without exception.

\section{Acknowledgements}

The author would like to thank all those who facilitated the research, in particular, the faculty of King Saud University.

\section{REFERENCES}

[1] Abdul Hakim, Farouk Jafar. (2011). University Governance, Introduction to the development of management through participation. Cairo, Journal of Educational Sciences, first issue, pp. 315-326.

[2] Abdul Kareem, Noha Hamed. (2006). Educational accountability as an input to evaluate the performance of the university faculty member. Ain Shams University, Center for the Development of University Education, 13th Annual National Conference of the Center for the Development of University Education "Arab Universities in the 21st Century: Reality and Vision", held during 26-27 November 2006.

[3] Abu Kareem, Ahmed Fathy, Al-Thwaini, Tarek Mohammed, (2014), the degree of application of the principles of governance in the faculties of education at Hail University and King Saud University as seen by the faculty members, Journal of Educational and Psychological Sciences, Volume 15 , issue 3, September 2014

[4] Al-Alawi, Alsayed Omar Shaker (2014), Corporate Governance in Jordanian and Kuwaiti Law, Unpublished Master Thesis, Amman Arab University, Faculty of Law. 
[5] Al-Hudayef, Omar bin Abdulaziz bin Suliman (2008), Implications of applying the basic principles of governance on the organizational and security performance of Saudi government agencies, unpublished doctoral thesis, Naif Arab University for Security Sciences, Department of Administrative Sciences.

[6] Al-Jarallah, Walid bin Mohammed. (2010). The applicability of governance in public organizations: A survey of public organizations in Riyadh. Unpublished Master Thesis, King Saud University.

[7] Al-Nassar, Mohammed bin Hamad (2014), Role of Governance in Reducing Money Laundering Practices in Saudi Insurance Companies, Unpublished Doctoral Thesis, Naif Arab University for Security Sciences, Department of Administrative Sciences.

[8] Al-Oraini, Manal bint Abdul Aziz. (2014). The reality of application of governance from the point of view of members of the administrative and academic bodies working at Imam Muhammad bin Saud Islamic University. Imam Muhammad bin Saud Islamic University, International Specialized Educational Journal, vol. III, issue (12), pp. 114-148.

[9] Al-Zahrani, Khadija Maqbool Jumaan (2011), The reality of applying good governance in Saudi private universities and its relation to job satisfaction and organizational loyalty of faculty members, unpublished doctoral thesis, Umm Al-Qura University, Faculty of Education, Educational Management and Planning Dept.

[10] Bratianu, Constantin. (2015). University Governance as a Strategic Driving Force. Bucharest, National University of Political Sciences and Public Administration.

[11] Deboer, Harry. (2013). The importance of governance in Higher Education Establishment: Field Study in the administration College in Millburn University. Millburn University: Studies in Higher Education, 35 (3) pp. 317-333.

[12] Dooley, Anthony. (2007). Thematic Analysis: the Role of Academic Boards in University Governance. Australia: Australian Universities.

[13] Hafiz, Abdulnasir Alak, Hussain, Hussain Walid, Khudair, Ibtehal Taleb (2012), the use of information technology in raising the efficiency of governance of higher education institutions, The sixth scientific conference of the Faculty of
Management and Economics, University of Basrah, 12-13 /11/2012

[14] Halawa, Jamal and Nedaa, Dar Taha (2014), the reality of governance at Al-Quds University, Ramah Research and Studies Magazine, Center for Research and Development of Human Resources, Jordan, issue 14, 2014.

[15] Ibn Manzoor, Abu Al-Fadl Jamal Al-Din (1983), Lesan Al-Arab, Cairo, Dar Al-Maarif.

[16] Irtwange, S. V. \& Orsaah, S.(2012). The fact of governance application in Mary Queen College in London University from the viewpoint of the professors. London University: Educational Research and Reviews, 5 (2) pp. 46-63.

[17] Khudair, Abtehal Talib (2012). The use of information technology in raising the efficiency of higher education institutions. University of Basra, The sixth scientific conference of the Faculty of Management and Economics, held from 12-13 November 2012.

[18] Lee, Lung-Sheng \& Land, Ming H. (2014). What University Governance Can Taiwan Learn from the United States? Submission, Paper presented at the International Presidential Forum (Harbin, China). No. 9, pp.9-14.

[19] Mahmoud, Madiha Fakhri. (2011). Analytical study of the concept of good governance and its application requirements in Egyptian universities. Cairo, Future Journal of Arab Education, Volume XVIII, issue 72, pp. 45-144.

[20] Miles, Jennifer. (2010). Higher Education Governance in Europe Policies, structures, funding and Academic staff Eurydice the European Commission Directorate-General for Education and Culture. Oxford University Press, June.

[21] Nassar, Asmaa Wajih Abdul Hafeez (2015), Impact of Application of Corporate Governance Mechanisms on Information Content in the Stock Market, "Applied Study", Scientific Journal of Economics and Trade, Egypt, issue 1, 2015.

[22] Nasser Al-Dean, Yaqoub Adel. (2012). The reality of application of governance at the University of Middle East from the point of view of the members of the teaching and administrative staff. Amman, Middle East University.

[23] Shukr, Abdul Ghaffar (2005). The educational and developmental role of NGOs and cooperatives in Egypt, Cairo, Egyptian General Book Organization. 